\title{
Extended Grammars: from SANSKrit to Middle INDO-ARYAN WITH REFERENCE TO VERB-DESCRIPTION
}

\author{
Nalini Balbir \\ University Sorbonne-Nouvelle Paris-3 \& École Pratique des Hautes Études, Paris, France
}

\section{Abstract}

Middle Indian languages belong to the same linguistic family as Sanskrit. But their grammarians offer a surprising contrast: literary Prakrits are described by grammarians who use Sanskrit, the most famous prescriptive model, which is thus extended. Pali, on the other hand, the language of Theravāda Buddhist scriptures, is described in grammars that make use of Pali. Possible reasons for this difference are considered here. Is the choice of Pali more than a superficial difference? Does the choice of Sanskrit prevent from taking into account features of linguistic reality? An attempt is made to answer these questions through the instance of verb-description and the treatment of the verb-root in grammars of the Middle Indian languages. How do the grammarians negotiate between the powerful Sanskrit model and the reality of verbal paradigms that tend to be based on the present stem and formed on a regular basis?

\section{Keywords}

Middle Indo-Aryan, Pali, Prakrit, Sanskrit, Pali grammarians, Prakrit grammarians, verbal root in Sanskrit and in Middle Indo-Aryan,

Kaccāyana; Aggavamsa, Vararuci; Hemacandra, Mārkaṇḍeya; Puruṣottama

\section{Résumé}

Les langues moyen-indiennes appartiennent à la même famille linguistique que le sanskrit, mais leurs grammaires présentent une situation contrastée: les prakrits littéraires sont décrits par des grammairiens qui utilisent le sanskrit, modèle normatif par excellence qu'elles étendent donc; en revanche, le pali (langue des écritures du bouddhisme Theravāda), est décrit au moyen du pali. Cet article examine les raisons susceptibles d'expliquer cette différence surprenante, alors même que prakrits et pali présentent de nombreux points communs dans leurs évolutions phonétiques ou morphologiques. Le choix d'une langue distincte, le pali, est-il plus qu'une différence superficielle? Inversement, le choix du sanskrit est-il un obstacle à prendre en compte les réalités des langues décrites? On tente de répondre à ces questions à partir d'un cas exemplaire : le fonctionnement de la description du verbe et le traitement de la notion de racine. Comment les grammairiens négocientils entre le modèle sanskrit omnipotent et la réalité de conjugaisons qui, tendant à prendre pour forme de base le thème du présent, développent des paradigmes réguliers?

\section{Mots-clés}

Moyen indo-aryen, Pali, Prakrit, Sanskrit, grammairiens du pali, grammairiens du prakrit, racine verbale en sanskrit et en indoaryen moyen, Kaccāyana, Aggavaṃsa, Vararuci, Hemacandra, Mārkaṇḍeya, Purușottama

\section{Preliminaries}

This paper will deal with some aspects of Indian grammars elaborated between the $7^{\text {th }}$ and the $17^{\text {th }} \mathrm{c}$. to edict rules or describe some of the linguistic stages that come under the broader heading 'Middle Indo-Aryan' (or Middle Indian). This 
designation refers to the intermediate linguistic stage between Old Indo-Aryan, namely Vedic and classical Sanskrit, and New Indo-Aryan which culminates ultimately in languages such as Hindi, Bengali, Marathi, Gujarati, etc. But one should not picture the relation between Old Indo-Aryan and Middle Indo-Aryan as chronologically layered. ${ }^{1}$ They are distinct stages, but from the earliest times Old Indo-Aryan has been influenced by Middle Indo-Aryan and there are close linguistic connections between both. It is admitted that at the same time a more polished speech (Sanskrit) was used in particular contexts and situations and coexisted with more vernacular dialects (Middle Indo-Aryan). Sanskrit, for which the absolute norm became Pāninin's grammar composed not later than the $4^{\text {th }} \mathrm{c}$. BCE, appears as the language of the intellectual elite, represented by the Brahmins. Middle Indo-Aryan, on the other hand, refers to the languages that were spoken by larger sections of the population. They spread even more from $500 \mathrm{BCE}$ because they were promoted by the Buddha, and by Mahāvira, the founder of Jainism. The oldest evidence of Middle Indo-Aryan dates back to the $3^{\text {rd }} \mathrm{c}$. BCE with the rock and pillar inscriptions engraved at strategic places of the Ashokan empire. The grammars on which this paper focuses deal with literary languages of Middle Indo-Aryan:

- Pali is the language of the Buddhist scriptures belonging to the Theravāda school $\left(1^{\text {st }} \mathrm{c}\right.$. BCE + in written form $)$ and represents the oldest linguistic stage of Middle Indo-Aryan.

- The term Prakrit refers to a plurality of related languages or dialects that have specific names and are used in various literary contexts: in classical Indian plays, in poetry, in stories or in the religious literature of Jainism. So it is better to speak of the Prakrits. The grammars of the Prakrits generally take one of them, called Māhārāsțrīi, the language of poetry par excellence, as the standard for description and devote separate sections to the special features of the other Prakrits. Here only facts relating to the treatment of this standard Prakrit will be discussed.

First, the most common types of linguistic differences between Sanskrit and the various Middle Indian languages are summarized here:

\section{Phonetic features:}

- Vocalic $r$ is replaced by $a, i$ or $u$.

- Diphthongs $a i$ and $a u$ are replaced by $e$ and $o$.

- Long vowels before two or more consonants are shortened.

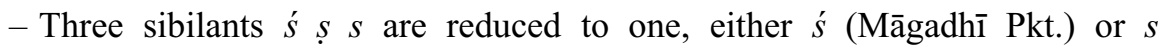
(elsewhere). 
- Complex consonant clusters are assimilated into geminate consonants or split through epenthetic vowel, e.g. Skt. sarpa 'snake' vs MIA sappa; Skt. ratna 'jewel' vs MIA ratana.

- Single intervocalic stops are weakened or removed, e.g. $3^{\text {rd }}$ pres. singular ending -ati (Pali), -adi (Śauraseni Pkt.), - ai (elsewhere).

- Dentals are palatalized by following -y-, e.g. Skt. satya 'truth' vs MIA sacca. ${ }^{2}$

\section{Structural features:}

- Case endings and developed inflections are at the same time same and different; there is a profusion and accumulation of forms existing side by side (older ones and new ones) but case endings differentiations are reduced in the latest stage of MIA (Apabhramsha).

- Three numbers: singular, dual, plural > MIA two numbers; dual is no longer alive and thus represents an irrelevant category.

- Developed verbal system > same and different; profusion and accumulation of forms existing side by side (older ones and new ones).

- Variety of past tenses $>$ progressive disappearance of several conjugated past tenses.

- Identical standard word order S O V in Sanskrit and MIA.

- Identical use of gerund to expand sentences in Sanskrit and MIA.

- Identical use of two balanced clauses as main subordination system in Sanskrit and MIA.

- Identical absence of indirect speech in Sanskrit and MIA.

The purpose here is only to highlight roughly the type of linguistic relations there are between all these languages, and the overall closeness they exhibit. In short, they are distinct but not fully alien to each other in their forms or grammatical structures. This point is meaningful if we turn to the issue of the metalanguages used by the grammars of Middle Indo-Aryan.

\section{Grammatical corpora of MIA}

Only the main landmarks of the vast corpus that grammatical works of MIA represent are listed here, underlining the striking difference that needs to detain us here between Pali and Prakrit grammars.

In all grammars of Pali the language of description is Pali:

- Kaccāyana's grammar $\left(7^{\text {th }}-10^{\text {th }} \mathrm{c}\right.$.), spread in all Theravāda countries. ${ }^{3}$ 
- Saddanīti by Aggavamsa (12 ${ }^{\text {th }}$ c.), composed in Burma. ${ }^{4}$

- Moggallāna's grammar $\left(12^{\text {th }}\right.$ c.): represents a different trend, spread in Sri Lanka. ${ }^{5}$

In all grammars of Prakrits the language of description is Sanskrit:

- Vararuci, the oldest Prakrit grammar $\left(3^{\text {rd }}-4^{\text {th }}\right.$ c. CE), very popular in various regions of India.

- Eastern school of grammarians represented by Puruṣottama (end of $11^{\text {th }}$ beginning of $12^{\text {th }}$ c.), Mārkaṇdeya $\left(17^{\text {th }}\right.$ c.), Rāmaśarman $\left(17^{\text {th }}\right.$ c.).

- Western school represented by two Jain authors: Hemacandra $\left(12^{\text {th }}\right.$ c. $)$ in Gujarat and Trivikrama (second half of the $13^{\text {th }}$ c.) in South India (Andhra Pradesh). ${ }^{6}$

All grammars conform to the traditional sütra form, namely concise aphorisms. Only two of them (Trivikrama and Rāmaśarman) put the contents into verses, which means adding verbs like 'are', 'should be' instead of keeping only to purely nominal sentences. All these grammars take recourse to the metalinguistic use of

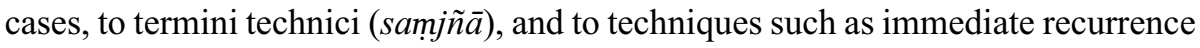
(anuvrtti) of a word from one aphorism to the next, all features met with in Sanskrit grammatical works, since Pāṇini’s Aștāähyāyō, the model par excellence, but not the only one.

\section{The choice of Metalanguage in Grammars of Middle Indian LANGUAGES}

Pali is described through Pali so that all Pali grammars are written in Pali. But Prakrits are described through the medium of Sanskrit. Thus the grammars of Prakrits can be described as 'extended Sanskrit grammars' in the strict sense: they use a language that has acquired an impressive cultural aura especially in scholarly areas in order to describe languages that are different from it. But the grammars of Pali come under this heading too: although they use Pali and not Sanskrit for the description, the descriptive model is clearly that of Sanskrit. ${ }^{7}$ Given the type of relationship between Sanskrit and Middle Indo-Aryan, the situation of extended

4 Smith, 1928-1966; Kahrs 1992b.

5 For full surveys see Franke 1902; Pind 2012 and Ruiz Falqués 2017.

6 This is no more than a sketchy chart for setting the context. Studies in the grammar of Prakrit languages are 170 years old in Europe, starting with Lassen (1837) and continuing with Pischel (1900) or Nitti-Dolci (1938). Kramadīśvara $\left(10^{\text {th }}-11^{\text {th }}\right.$ c.?), popular in Eastern India, is not considered here.

7 Precisely identifying which Sanskrit grammar is the model of a given Pali grammar is not the purpose here. The Kätantra and the Cāndravyākarana are among the two main sources. For this issue see, among others, Franke 1902; Renou 1957; Pind 2012; Deokar 2012b showing the influence of the Kätantra and its commentaries on Aggavamsa's work, Ruiz Falqués 2017. 
Sanskrit grammars of Middle Indo-Aryan is quite different from extended Sanskrit grammars applied to Indian languages of other families, such as the Dravidian languages, where there is a wide structural gap between the language of description and the language described.

What could be the reasons for the contrastive situation in metalanguages we observe between Pali and Prakrit grammars? They largely relate to the perception the grammarians of these traditions have of the languages they describe. This presides over their rejection or adoption of Sanskrit as their metalanguage.

\subsection{Perceptions of Pali}

I select Aggavamsa (the $12^{\text {th }}$ century Burmese monk author of the Saddaniti) as my representative of the Pali attitude, for his grammar has the advantage of providing us with a developed and coherent discourse in his own commentary of the sütras. Right at the start he explains that his work is meant to elucidate all the implications of the Buddha's teaching (buddhavacana) so that there is no confusion on letters and words. As a Theravāda Buddhist, his belief is that the Buddha preached in the language Buddhists call Māgadhī, that is Pali. His grammar is imbibed with an extremely large number of quotations from the scriptures with which he had an unmatched familiarity. So, for him, the question even does not arise of using a language other than Pali. The same holds true for his predecessor, Kaccāyana, but the latter seems to take it for granted and does not elaborate on this point.

In addition, Aggavamsa also announces his desire to cleanse the language (visodhana), as he says, of forms that he considers foreign to the Buddha's speech. ${ }^{8}$ They are those coming from the pressure of Sanskrit against which he raises his voice. He cannot fight against admitted Sanskrit loanwords that have crept in Pali and look unusual because they contain a consonant cluster that has not gone through assimilation. Among them there are words that are used only in their Sanskrit form such as indriya 'sense organ', brāhmaṇa, 'brahmin', as well as some which can be used either in their Pali form (with consonant group disjunction) or in their Sanskrit form (with consonant group maintained) such as ratana versus ratna 'jewel', paduma versus padma 'lotus', kilesa versus klesa 'defilement'. The grammarian can only note the existence of those belonging to the first group, as there is really no other choice: such words are found all over in the texts reflecting the Buddha's teaching. For words known under two forms, however, he tries to delineate a distribution principle, noting that the Sanskritic forms are mostly found

8 Sadd 924,9-10: pariyatti-sāsane āharitvā vuttānam a-māgadhikānam añ̃̃esam saddānaṃ visodhan'-attham ayam pi pan' ettha nīti sādhukaṃ manasi-kātabbā.

9 See the detailed discussion of Sadd 923,24-924,5. 
in verses. ${ }^{10}$ Similarly, he separates himself from others who recognize the Sanskritic form guru in the meaning 'teacher' and the Pali form garu in the meaning 'elders', only admitting garu and using it throughout his grammar. ${ }^{11} \mathrm{He}$ criticizes his predecessor Kaccāyana who postulates forms such as uccate 'is said', present passive $3^{\text {rd }}$ singular, and uttam 'said', past participle, and opposes to them the expected Pali forms, respectively vuccati and vuttam: ${ }^{12}$ the former are mechanical transpositions of Skt. ucyate and uktam, whereas the latter exhibit Pali phoneticism with initial epenthesis and a Pali morphological feature for vuccati, with the active ending - $t i$ used for the passive as it is common in Pali. But there is a certain amount of fluctuation: in one place he considers the Sanskritic form kriya 'action' as a borrowing and kiriy $\bar{a}$ as the only valid form in Pali, but, elsewhere, however reluctantly, he admits kriya $\bar{a}$ relying on the authority of the "commentariesauthors' ${ }^{13}$ His general stand, which is to criticize the scholars deceived by their familiarity with Sanskrit books, leads him to reject Sanskritisms in individual words ${ }^{14}$ and to state specific rules, for example in the area of sandhi ${ }^{15}$ where the pressure of Sanskrit was probably high. All this shows how uneasy the fight to defend the Pali linguistic identity is and how the Sanskrit influence acts as a diktat.

The Sanskrit grammarians and, to some extent, the later Pali commentators, are Aggavamsa's favourite targets. This can be seen, for instance, in his discussion of the dual. ${ }^{16}$ This grammatical number is no longer alive in Middle Indo-Aryan, and thus represents an irrelevant category in this linguistic stratum. But the occurrence of a specific form of the pronoun used in connection with two monks in the Vinaya (books of monastic discipline), contrasting with another form in the case of three or four monks, raises a question. Aggavamsa violently goes against those who would claim on the basis of this form that the dual exists in the Buddha's speech. This form is specific of the Vinaya language, he says, but it cannot be said to represent a general situation. His conclusion is clear: 'The dual number exists in the Sanskrit language for two (items), but in Pali it does not exist'. ${ }^{17}$ This leads to what seems to

10 Sadd $204,24 \mathrm{ff}$.

11 Sadd 923,3-14.

12 Sadd $924,6-8$ and also $336,10-11$.

13 Sadd 923,18-23 and 516,27ff.; von Hinüber 1983, p.71. This is a crucial study on Aggavamsa's position towards Sanskritic pressure, on his 'occasionally rather far reaching spirit of innovation' (p.73) and on the relationship between the grammarian and the manuscript tradition he must have had access to.

14 There are several examples of this type: candam $\bar{a}$ 'moonlight' is rejected as a Sanskritism in favour of candima $\bar{a}$, the common Pali form attested in the sacred text $(793,20 \mathrm{ff}$.); laghim $\bar{a}$ 'lightness' is rejected for the same reason in favour of lahima $(867,1 \mathrm{ff}$.). See Deokar 2012a, p. 6-9 for further discussion of different examples.

15 See Sadd 614,12-22.

16 Sadd 92,16-93,22.

17 Sadd 93,12-13: sakkața-bhāsāyam dvīsu pi dvi-vacanāni santi, Magadha-bhāsāyam pana n'atthi. 
be the coinage of a new grammatical term, i.e. puthu-vacana as a designation of plural (instead of the common Sanskrit term bahu-vacana also used by other Pali grammarians). This word is supposed to convey at once 'the difference' there is in what plural means in Pali and in Sanskrit. ${ }^{18}$ In Sanskrit, dual is used for 2 not for 3 , 4, 5, etc., but in Pali the plural is used for 2, 3, 4, 5, etc.

The discussion of grammatical gender is another of his concerns. For instance, he establishes the masculine gender and the singular number of the word apo 'waters' on the basis of quotations. But in one passage of a late sub-commentary $(t \bar{i} k \bar{a})$ this word is found used in the feminine plural ${ }^{19}-$ like in Sanskrit. Although exonerating the sub-commentators and paying respect to them $(116,3-5)$ the grammarian says:

These (subcommentators) were not only conversant with the Buddha's speech, the Tipitaka and its commentaries, but also with the whole of (Sanskrit) grammar. That is why, having borrowed the rule found in Sanskrit grammar, they have described the word apa as a feminine plural in order to show their own proficiency in grammar, and to make known to others that such was the rule in Sanskrit grammar'. ${ }^{20}$

One of the reasons he finds to this situation is that there is 'sometimes a complete disagreement between the rule of the sacred text and the rule of the Sanskrit grammarians', ${ }^{21}$ with the result that 'in Sanskrit grammar the word 'water' is feminine plural, in the speech declared by the Buddha it is masculine singular'. 22

So he obviously sees the pressure of Sanskrit, increasing in his time, as a threat and behaves as a Pali purist. To sum up: Pali grammars are meant to elucidate all the implications of the Buddha's teaching. For Theravāda Buddhists, the language of the Buddha is what they call 'Māgadhī', what we call Pali. Therefore, no other

18 Sadd 93,14-32. Pa. puthu < Skt. prthag 'separate, different', explained as visum-bhūta (Sadd 93,16ff.). Pa. puthuvacana is not discussed in Deokar 2008, p. 181-184 about the terms referring to 'number' (vacana) although one occurrence in Sadd is mentioned.

19 Sadd 107,25-26: appo ... honti (present plural $3^{\text {rd }}$ person), tâsam (demonstrative, genitive plural feminine)...

20 Sadd 115,29-33: yasmā pana te na kevalam sātthakathe tepitake buddha-vacane yeva visāradā atha ko sakale pi sadda-satthe visāradā, tasmā sadda-satthe attano pandiccam pakāsetum sadda-satthe ca ídiso nayo vutto ti pare viñ̃ñpetuñ ca sadda-satthe nayam gahetvā àpa-saddassa itthi-linga-bahuvacanakattam vannesum.

21 Sadd 700,10-11: katthaci katthaci thāne yebhuyyena pālinaya-saddasattha-nayānam aññamañnam accanta-viruddhattā ca.

22 Sadd 700,12-13: sadda-satthe āpa-saddo bahuvacan'-antam itthi-lingam, Bhagavatā āhacca bhāsite pullingam eka-vacan'-antam. Similar kinds of discussion deal with the gender of the words dhâtu 'element' (206,5-9), or the grammatical gender of words designating female individuals such as dāra 'wife' $(98,19 \mathrm{ff}$.), orodha 'harem' $(95,1-99,12)$ or mātugāma 'womanfolk' which are not necessarily feminine. One has to distinguish, he argues, between meaning and grammatical congruence (102,13-15), deciding for masculine singular for orodha and masculine plural for mātugàma. 
language needs consideration. The grammars contain numerous quotations from the scriptures and are viewed as instances of the Buddha's word. Sanskrit and 'Sanskrit grammars' (Pa. sadda-sattha / Skt. śabda-śāstra) are felt as a pressurizing threat, especially in Middle Ages South East Asia where Sanskrit language and its literary tradition expand their influence.

\subsection{Perceptions of the Prakrits}

Let us now come to Prakrit. The first work where Prakrit is somehow dealt with is the Nätyaśästra - not a grammar, thus, but a treatise on poetics and dramaturgy. In brief, in classical Indian plays, Sanskrit is spoken by some characters and Prakrit by others. In this context, Prakrit is considered 'as the spoken form of Sanskrit, with deviating pronounciation here and there. Hence Prakrit is in Bharata's opinion not a different language; Sanskrit and Prakrit are different variants of the same language'. ${ }^{23}$

Several grammars in the corpus start in medias res with the treatment of vowels which invariably is their first topic. ${ }^{24}$ They have no preamble of any sort or any thought on the process of writing etc. In such cases, the fact that their starting point is Sanskrit, however, becomes clear from statements found here and there such as: 'The roots which are known here (= Sanskrit) as ending in consonants will be changed in Prakrit to roots ending in $a$ ', says Rāmaśarman, for instance. ${ }^{25}$ This is a way to express the process of transfer to thematic paradigms which is a prevalent morphological feature in Prakrit and one of the main differences with Sanskrit.

Other grammars, on the other hand, offer as a preliminary an interesting discourse which throws light on their perception of Prakrit. They clearly view it as 'derived' from Sanskrit. They do recognize the existence of words that are not connected with Sanskrit, but they do not consider them as the subject of their grammars. Authors who treat these words do it in special works, such as dictionaries of regional words. ${ }^{26}$ I here briefly review a few famous passages that have already been dealt with in scholarship.

Hemacandra's grammar of the Prakrits comes after seven chapters devoted to Sanskrit. Hence he starts 'And now Prakrit' and explains:

The basis is Sanskrit. That which is located there or has come from there is Prakrit. Immediately after Sanskrit Prakrit is established as the new topic.

23 Verbeke 2010, p. 13.

24 E.g., Vararuci, Rāmaśarman; the beginning of Purusottama is missing.

25 ye dhātavo 'tra prathitā hal-antās / te prākṛteșv eva bhavanty ad-antāḥ, (Rāmaśarman 1.7.1, translation by Ghosh p. 107).

26 Such words are labelled as 'local' or 'regional' (desín). Examples of such repositories are Dhanapāla's Pāialacchīnāmamālā $\left(10^{\text {th }} \mathrm{c} . \mathrm{CE}\right)$ or Hemacandra's Deśīnāmamālāa $\left(12^{\text {th }} \mathrm{c} . \mathrm{CE}\right)$. See for instance Drocco 2012. 
And the fact that teaching about Prakrit comes immediately after Sanskrit has the purpose of implying that the body of rules is only for that which has Sanskrit as its origin in either of its (two) categories: words that have already been formed ${ }^{27}$ and those that are in the course of being formed, ${ }^{28}$ not to regional (words). As for what is identical with Sanskrit, it has already been explained through the rules meant for Sanskrit. In Prakrit too one speaks of base, affix, gender, cases, compounds, technical terms, etc. ${ }^{29}$

The grammarian then lists obvious and crucial general differences between Prakrit and Sanskrit in terms of phonetics and morphology: the sound system is the same except that vocalic $r$, short and long, vocalic $l$, short and long, the diphtongs $a i$ and $a u$, the guttural and palatal nasal, the palatal and retroflex sibilant, the visarga and the plüta do not exist in Prakrit. The guttural and palatal nasal are found only in consonant groups; ai and au may be found occasionally. A consonant without vowel is not found. The dual and the dative plural are not attested. ${ }^{30}$ Thus we see right at the beginning that Sanskrit is viewed as the explicit and obvious model and that the purpose of the grammar is to consider the features that make Prakrit different from Sanskrit.

Trivikrama, who works along the line of Hemacandra, has a similar discourse in the opening verses of his grammar and in the first sütra. But he first states that a word which has much meaning and which is easily pronounced is the soul of poetry and it is also Prakrit, thereby ascribing a positive value to this language and referring to one of its main applications. He then recognizes that there are forms of the language that depend on use ( $r \bar{u} d h a)$, that they are quite independent and hence do not stand in need of grammar. Only tradition can give information about them. The Prakrit forms and words which are treated in his grammar are those which can be subjected to rules of grammar and can be traced to fully formed Sanskrit words (siddha) or words in the course of being formed (sādhyamāna). ${ }^{31}$

Marrkandeya in the $17^{\text {th }} \mathrm{c}$. is in tune with this position, which he repeats at the outset:

Sanskrit is the base. What comes from there is called Prakrit. There are two kinds of words: originating from it (i.e. Sanskrit) and identical to it, and some say there is also regional (vocabulary).

27 See the commentary on Hemacandra 2.146 which takes as an instance Pkt. vandittā 'after having paid respect' (absolutive), coming from Skt. vanditv $\bar{a}$ with the disappearance of $v \bar{a}$. 28 E.g., a nominal or verbal stem not yet provided with endings.

29 Hemacandra's commentary on the first aphorism of his Prakrit grammar.

30 Hemacandra's commentary on the first aphorism of his Prakrit grammar (continued).

31 Beginning of commentary, vss 7-8. See Nitti-Dolci 1938, p. 187-188 [1972, p. 196]. 
Commentary: A tadbhava exists in Sanskrit and has assumed another form through rules, like rukkha 'tree', ghara 'house', peranta 'end'. Examples of a tatsama are tarala 'trembling', taranga 'wave', manthara 'slow', etc. A regional (word) is not realized by the rules, it is known in this or that region and used by great poets, such as ladaha 'handsome', petta 'belly' or tokkha '?', 32

This is a tripartite classification which dates back to the $7^{\text {th }} \mathrm{c} .{ }^{33}$ and has become a common tool to describe not only Prakrit but also New Indo-Aryan vocabulary.

One caveat about such passages: the grammarians take into consideration the variety of Prakrit and especially of its vocabulary which draws upon all sorts of sources. What they mean to say is that the focus of their grammars is on those words of the language for which rules can be edicted and systematized. This is why they concentrate on substitution rules. This probably reflects their aim, namely to provide the knowers of Sanskrit with the equipment allowing them to understand how Prakrit works, and this motivation also accounts for the choice of Sanskrit as metalanguage. Whether these grammars alone are sufficient to enable anybody to write fluent poetry of high quality in Prakrit is however doubtful. The overwhelming number of substitution rules from Sanskrit to Prakrit characterizing these grammars is probably what has contributed to spread a kind of mechanical vision of Prakrit as restricted to a language having a derivational status.

Nevertheless, other challenging views on what Prakrit is do exist. An $8^{\text {th }}$ c. poet, for instance, who wrote an epic poem in Prakrit, is radically different:

All forms of speech enter (Prakrit) and all forms of speech start from it: waters enter nowhere but into the sea and start from nowhere else than from the sea. ${ }^{34}$

This statement may have to be assessed cum grano salis as the author is a connoisseur of Prakrit who is keen on promoting the language as a fullfledged literary language in no way inferior to Sanskrit. But it is echoed in the $11^{\text {th }} \mathrm{c}$. by another intellectual, the Jain commentator Namisādhu:

prakrti is the natural use of speech made by all beings of the world which is not refined by grammar etc.; that which is derived from this prakrti itself is prā $k r t a .^{35}$

Another internal etymology he provides is prākrta as 'that which has been created first' (prāk krta). He then explains how Prakrit and Sanskrit are related:

Präkrta is the speech easily intelligible to children, women etc. and the source of all other speeches (sakala-bhāsā-nibandhana-bhütam vacanam). It is of a

32 Mārkaṇdeya verse 1 and corresponding commentary (in Acharya 1968, p. 3-4; translated in Verbeke 2010, p. 33).

33 See Kahrs 1992a, p. 227.

34 Gaudavaho 93 by Vākpati, quoted and translated for instance in Scharfe 1977, p. 191.

35 On Rudrața's Kāvyyālaṃkāra 2.12 (quoted in Houben 1994, p. 5). 
homogeneous character like rain falling from the clouds. That same speech, being differentiated according to differences in place and on account of refinement, obtains the subsequent division into samskrta and other speeches. Samskṛta is called so on account of being refined by Pānini and others, in the rules of their grammar. ${ }^{36}$

In this approach, Prakrit comes first and Sanskrit second. The prākrta words are original, and the samskrtas are those which have been transformed. In short, one has to distinguish between a general view on the relationship between Prakrit and Sanskrit and a particular application of it in the context of grammatical rules. But that there is a direct relationship and that one cannot go without the other is a recurring idea, and this is in sharp contrast with the Pali attitude.

\section{Grammars of Middle Indian on the verb: how to Negotiate With SANSKRIT MODELS}

Through a case-study, a few aspects of verb-description, we will try to investigate how the grammarians of Pali and Prakrit negotiate between the Sanskrit models and the reality of the languages they describe. How much impact does the selected metalanguage (Pali/Sanskrit) really have?

\subsection{Active and middle voice endings}

In Sanskrit, each tense or mode is conjugated both in the active voice (parasmaipada) and in the middle voice (atmanepada) quite systematically. But in Prakrit the middle voice is regressing. Here is how Vararuci deals with the conjugation of the present singular. ${ }^{37}$

For the affixes of the third person singular in the active and middle voice $-i$ and $-e$ are the endings in Prakrit. Thus padhai (active), padhae (middle) 'he recites' or sahai (active), sahae (middle) 'he endures' in front of Sanskrit pathati (active), pat hate (middle) or sahati (active), sahate (middle).

For the affixes of the second person singular in the active and middle voice -si and -se are the substitutes. Thus padhasi, padhase 'you recite' or sahasi, sahase 'you endure' in front of Sanskrit pațasi, pathase or sahasi, sahase. The forms are identical in Prakrit and Sanskrit, except for the voicing of the intervocalic consonant in Prakrit.

Now, for the affixes of the first person singular in the active and in the middle voice, both, $-m i$ is the only substitute taught. Thus Prakrit has only padhämi 'I recite', hasāmi 'I laugh', sahāmi 'I endure' - where Sanskrit would have pațāmi, hasāmi, sahāmi in the active and pathe, hase, sahe in the middle voice. 
Here we see that, although the grammarian of Prakrit undertakes to achieve a systematic presentation where the forms of both the active and middle voice are considered for the three persons and are distinct from each other, he has to give up the binary opposition in the case of the first person singular probably because he takes into account the real usage of the language where this form in the middle voice is not attested. The position of Vararuci, just described, is shared by Hemacandra and Mārkạ̣deya. ${ }^{38}$ But a more radical stand is adopted by Puruṣottama. He prescribes only one substitute for both voices, not only for the first person singular, but also for the second and the third:

Instead of the affixes of the active and middle voice in the third person singular there is $-i$ (6.2). Instead of the affixes of the active and middle voice in the second person singular there is -si (6.4). Instead of the affixes in the active and middle voice in the first person singular there is $-m i$ ' (6.7).

This amounts to denying any specific existence to an independent conjugation in the middle voice. Similarly Vararuci does not teach -nte, the third plural ending in the middle voice, which, indeed, is unknown in the dialect he describes. ${ }^{39}$ Such an example illustrates the tension between the Sanskrit model and pattern of conjugation to which the grammarians of Prakrit are indebted, on the one hand, and the relevance of this model in respect with specificities of the Prakrit that do not fit in, on the other. The solutions are either the compromise or the innovation.

\subsection{A special syntactic use of the Prakrit present participle}

Given their basic postulate and their perception of Prakrit as being derived from Sanskrit, the grammarians of Prakrit focus predominantly on the description of phonetic and morphologic differences. Syntactic facts are rarely considered. ${ }^{40}$ One instance, however, of a specific syntactic use relating to a given verbal form, namely the present participle, is dealt with by three Prakrit grammarians:

- Puruṣottama 6.32 lrinah śatrvat 'The conditional is replaced by the present participle'.

38 Hemacandra 3. 139-141 with trtizyasya mih 'ending $-i$ for the first person singular'; Mārkanḍeya 6.6 (see Nitti-Dolci 1938, p. 110 [1972, p. 115]. In their commentaries Hemacandra and Mārkaṇ deya provide examples of first person singular in -aṃ, which indeed are found in Māhārāṣțī Prakrit.

39 Cf. Nitti-Dolci 1938, p. 113 ([1972, p. 118].

40 To some extent similar observations hold true for Pali grammars as well, see Pind 1995, p. 295-297. 
- Hemacandra 3.180 nta-mānau 'The active present participle and the middle present participle' (are substitutes for the conditional).

- Mārkaṇḍeya 6.18 lriniarthe vā (śatr-śānayor nta-mānau) 'The present participle, both active and middle, may also stand in the meaning of a conditional' ${ }^{41}$

Indeed, even if the middle voice is mostly not alive and productive in Prakrit, the middle present participle is common and, as a nominal form, stands apart from the general system.

Hemacandra provides a poetical verse as illustration:

O moon (litt. the one with the deer as a mark), if you had placed the lion (litt. the master over the deer) [on your body] instead of the deer, you would not have had to endure the insult of Răhu (= the eclipse), the one who wins. ${ }^{42}$

As for Mārkaṇḍeya, his examples are simpler: 'If he would read, he would be learned' or 'if he would eat, he would feel satiated'. ${ }^{43}$ This sentence pattern, where the present participle functions as the main verb in both parts of the conditional system, is met with very often in Prakrit and corresponds to a linguistic reality. Although it is occasionally attested in Sanskrit too, it remains marginal and is characteristic of a non-formal style. In the evolution of Indo-Aryan, on the contrary, it tends to become the prevalent pattern. ${ }^{44}$ Such a case shows how using Sanskrit as the metalanguage and conventional grammatical terminology does not prevent the grammarians from taking into account, at least occasionally, facts that are typical of the language they describe.

\subsection{Middle Indian and the verbal roots}

In the Sanskrit grammatical tradition the verb is based on a root, dhätu. These roots are classified into ten groups (gana) depending on the type of present formation they use.

41 Cf. Nitti-Dolci 1938, p. 110 with French translation [1972, p. 118]. According to her this is an innovation of the Eastern school of Prakrit grammarians but it is also attested in Hemacandra as she indicates as well. Compare Trivikrama 2.4 .41 which does not mention any illustrative sentence.

42 Text and translation based on Hemacandra as in Vaidya: harina-țthāne harin'-añka jai si hariṇāhivam nivesanto / na sahanto ccia to rāhu-parihavam se jiantassa. Rāhu also called 'the son of Simhikā', a lioness. Pischel's ed. has a simplified version where all the wordplay elements are lacking (and are mentioned as variants).

43 jai padhanto (active present participle), tā pandido homto (active present participle) or jai bhumjamāno (middle present participle) tā thippamāno (middle present participle), quoted under 6.18. Sentences of this type are common in Māhāāasțīī Prakrit, as well as in Apabhramśs.

44 See examples in Bloch 1965, p. 259-260. 


\begin{tabular}{|c|c|}
\hline 1. $b h \bar{u} v-\bar{a} d i$ & Thematic conjugation with vowel gradation (bhavati) \\
\hline 2. $a d-\bar{a} d i$ & Root class with variation between strong and weak forms in the root (atti) \\
\hline 3. juhoty-ādi & Reduplicated class with variation in the root (juhoti) \\
\hline 4. $d i v-\bar{a} d i$ & Thematic conjugation with suffix $-y a-($ divyati) \\
\hline 5. $s u-\bar{a} d i$ & Root suffixed with the varying suffix $-n o-/-n u-($ sunoti) \\
\hline 6. tud-ādi & Thematic conjugation with no vowel gradation (tudati) \\
\hline 7. rudh-ādi & Infix nasal class with variation in the infix $-n a-/-n-($ runaddhi) \\
\hline 8. $\tan -\bar{a} d i$ & Root suffixed with the varying suffix $-o /-u$ - (tanoti) \\
\hline 9. $k r \bar{r}-\bar{a} d i$ & Root suffixed with the varying suffix $-n \bar{a}-/-n \bar{l}-(k r \bar{i} n \bar{a} t i)$ \\
\hline 10. cora-ādi & Thematic conjugation with suffix -aya- (corayati) \\
\hline
\end{tabular}

Let us see the status of these groups in Middle Indo-Aryan grammars. At least two of the most important grammarians of Pali belonging to the same line of teaching, namely Kaccāyana and Aggavamisa, make use of this classification, but they contain adjustments to the linguistic reality of the language they describe.

\begin{tabular}{|c|c|}
\hline 1. $b h u v-\bar{a} d i$ & (Skt. Class 1) \\
\hline 2. $r u d h-\bar{a} d i$ & (Skt. Class 7) \\
\hline 3. $d i v-\bar{a} d i$ & (Skt. Class 4) \\
\hline 4. $s v-\bar{a} d i$ & (Skt. Class 5) \\
\hline 5. kiy-ādi & (Skt. Class 9) \\
\hline 6. gah-ädi (see below) & No independent Skt. class \\
\hline 7. $\tan -\bar{a} d i$ & (Skt. Class 8) \\
\hline 8. cur-ādi & (Skt. Class 10) \\
\hline
\end{tabular}

Both of them record only eight groups and not ten: group 2 (root present stems with variation between strong and weak grade) and group 3 (reduplicating presents with variation between strong and weak grade) are irrelevant in the language they describe and are thus left out as groups. ${ }^{45}$ In addition, the sequence of the groups is different from the traditional one. The thematic conjugations, which correspond to class 1, 4, 6 and 10 in the Sanskrit descriptions, are reduced to three groups, because the distinction between thematic presents with and without vowel gradation is abolished. This results into the disappearance of class 6 (tudati) as an independent entity and into its merging into class 1 . But, on the other hand, a new class is added, the group gahädi. The root gah means 'to seize, to take hold of',

45 Kacc 447-454 et Sadd, Suttamālā 925-926, 928-933; see also Sadd 2,21-23: ganato te ațt havidhā: bhuvādi-gaṇo, rudhādi-gano, divādi-gaṇo, svādi-gaṇo, kiyādo-gaṇo, gahādi-gaṇo, tanādi-gano, curādi-gano cā ti. Note that Moggallāna VI deals with the verb but apparently does not include any reference to the ganas, the root-groups. 
corresponding to Skt. GRH, grhnāti which is a member of class 9. The existence of a specific sütra for this verb and a wording comparable to other aphorisms describing verb classes make it clear that Kaccāyana considers gaha as the leader of a separate class: 'After gaha etc. (the suffixes are) $p p a$ and $n h \bar{a},{ }^{46}$ hence the present forms gheppati and ganhāti. While Kaccāyana remains content with this statement, Aggavamsa marks his awareness of the fact that this is not something accepted by all and explains why the existence of a distinct class is justified, referring to Kaccāyana's authority:

Here there are some people who think as follows: indeed, a separate group for gaha etc. is not attested. How could there be a group for gaha etc. with only one root? Because $p p a$ and $n h \bar{a}$ are not found after any other root than gaha, there are some who have included this root in the group of kiy 'to buy' (Skt. kri-) without speaking of a group ' $g a h a$ etc.' A wise man, an expert would not accept their view because Kaccāyana in his rule has established a separate group for gaha etc. ${ }^{47}$

Since the case of this root has not been included in the rule relating to the root 'to buy' and since the wording has ' $g a h a$ etc.' and not ' $g a h a$ ' only, it means it refers to a group. And, he argues, there is, indeed, a group. He then treats verbal forms showing the consonant sequence -ṇha-, such as unhati 'is warm', unhhāpeti 'makes warm', etc. Whether the demonstration is fully convincing is another matter. But we see the polemic tone in the discussion and the role played by the authoritative reference of Kaccāyana. Making the root gaha the leader of an independent class attracts attention to its specific forms in Pali usage which cannot really be explained by reference to other verb classes.

Finally, the inclusion of a given form within one class or the other may become a matter of discussion in case there is a conflict between the teaching of the (Sanskrit) grammarians and the Pali scriptures. This is what happens with Pa. paccati used as non-transitive in the sentence 'Devadatta is roasted in hells'. ${ }^{48}$ The meaning requires, Aggavamsa says

46 Kacc 452: gahädito ppa-ṇhā, comparable to, for instance, divādito yo (449) or any other sūtra in this group. But two points deserve to be noted: 1) Senart's edition (1871, p. 239), following d'Alwis 1863, and later also Vidyabhusana 1901, read $c a$ at the end of the sūtra. Senart takes this as a proof that there is no special class for gaha: 'ca marque le passage du général au particulier: le sens est: en général les racines de la classe kî prennent nâ, et gah prend, etc. - en effet gah est tout naturellement considéré comme faisant partie de la classe kyâdi ... et non, malgré adito, comme tête d'une classe spéciale, qui, comme le remarque M. d'Alwis (p. 20), n'existe pas' (On the sometimes loose and problematic usage of $c a$ in Kaccāyana see Deokar 2008, p. 365-366); 2) in the Kaccāyana Dhātumañjūsāa, gaha upādāne (731) is included in the group kiyādayo (Andersen and Smith 1921, p. 47) and does not feature as a separate group in the final counting where the total number is 7 and not 8: bhuvādi ca rudhād $\bar{\imath}$ ca divādī svādayo gaña / kiyādì ca tanādī ca curādì cìdha sattadhā (verse 151 in Andersen and Smith 1921, p. 152).

47 Sadd 502,4-12 (verses).

48 Sadd 339, 6 Devadatto niraye paccati. 
that the verb belongs to the class $d i v-\bar{a} d i$ (intransitive or stative verbs using the suffix $-y a$-in Sanskrit). If it is objected that the root $p a c$ - has not been listed in this group in the (Sanskrit) grammars, the answer is: whether it is or not, how does the (Sanskrit) grammars matter? The sacred text only is the authority. Therefore, considering only the sacred text of the Buddha, who is an expert in idiomatic language, I will put this root also in the group $d i v-\bar{a} d i{ }^{49}$

Since Pāṇini onwards, there are special collections, called Dhātupāthas, where the Sanskrit roots are listed according to the above mentioned classification (Palsule 1955). Such collections do exist also for Pali: the 'garland of roots' (Dhātumālā) structures Aggavamsa's whole work and is at the centre of five long sections. ${ }^{50}$ In addition at least two separate collections are also known for Pali: a Dhātupātha and a Dhātumañjusā. ${ }^{51}$ This is in tune with the fact that Pali grammarians acknowledge the tenfold classification as an organizing principle for the Pali verb, even if they adjust it to the requirements of the language they describe.

By contrast, the situation is totally different for Prakrit: we do not have collections of roots. In her seminal monograph Nitti-Dolci tried to explain this absence: first, she argues, Prakrit grammarians must have thought that the students could consult the Sanskrit Dhätupāthas and somehow manage to build the Prakrit verbal forms thanks to the analogy with the noun system. In fact, she adds, the Prakrit grammarians were well aware of the difficulty to adapt their often artificial and ad hoc system of phonetic correspondances to varying units like verbal stems. 'From a single Sanskrit root, she concludes, are derived different themes, that, in their turn are combined with varied affixes: every case falls under the stroke of a different phonetic rule. ${ }^{52}$ In fact, although the grammarians of Prakrit use Sanskrit as their language of description, they do not seem to be as much influenced by the Sanskrit norm as one could first think when it comes to the verb. In Prakrit cards are shuffled and we see several changes or transfers of conjugational patterns. Here is an example of the way grammarians deal with this issue:

Vararuci 8.29 ciñaś ciṇah: 'Instead of $c i$ - there is cina', so present $3^{\text {rd }}$ person singular cinai. The starting point is the root in the form adopted in Sanskrit collections: cin cayane. ${ }^{53}$ Although it is listed in the tenth group, where the

49 Sadd 339, 29-33: akamma-kattu-vācakattā kamma-rahita-suddha-kattu-vācakattā ca paccatī ti idam divādi-ganika-rūpan ti datțhabbaṃ. paca-dhātu sadda-satthe divādi-gaṇe vutto n'atthī ti ce. -n'atthi vā atthi vā; kim ettha sadda-sattham karissati, pạ̄lì eva pamānam tasmā mayaṃ loka-vohāra-kusalassa Bhagavato pāli-nayañ ñeva gahetvā imaṃ paca-dhātum divādi-gane pi pakkhipissāma.

50 Sadd, Dhātumālā, p. 315-602.

51 See Andersen and Smith 1921 and Katre 1940.

52 Nitti-Dolci 1972, p. x (1938, p. 7).

53 Dhātupātha 1629. 
present marker is -aya-, hence cayati, this present formation is limited to Vedic Sanskrit, the oldest stratum of the language, while the common present is cinoti, so class 5 according to Sanskrit classifications.

Vararuci 8.56 śru-hu-ji-lu-dhuvām no 'ntye hrasvah: 'At the end of roots śru "to hear", $h u$ "to offer", $j i$ "to conquer", $l \bar{u}$ "to cut", $d h \bar{u}$ "to shake" $n a$ (is to be employed) and (the preceding vowel if long) is shortened, e.g. sunai, hunai, jinai, lunai, dhunai. ${ }^{54}$

Hemacandra 4.241 ci-ji-śru-hu-stu-lū-pū-dhūgām ṇo hrasvaś ca ${ }^{55}$ adds two more instances to the preceding list. The commentary also expands by adducing the sutra tool bahulam 'generally' (Hc 1.2) in order to cover the doublet forms optionally attested in Prakrit, for example uccei beside uccinai or jayai beside jiṇai.

What we see here is that the use of Sanskrit as the metalanguage is no hindrance to a purely synchronic description of verbal forms. Those which behave in the same way in Prakrit are listed together. The fact that they belonged to other conjugational patterns in Sanskrit, which, in addition, are not the same for all the roots listed, is irrelevant at the sütra level. As for the commentators, they are generally satisfied with listing the present form of the roots, although they occasionally comply with the Sanskrit diktat and give the equivalent Sanskrit form. ${ }^{56}$ All the verbs of this list illustrate the overwhelming tendency of Prakrit to develop thematic verbal stems, where Sanskrit had roots or suffixes varying between strong and weak grade. The adjunction of the affix - na- in all of them makes these verbal stems thematic and puts all the roots of the list at the same level.

Similar remarks would hold true for the treatment of the former Sanskrit class 7 characterized by the varying nasal infix, -na- (strong grade) / - $n$ - (weak grade), e.g. root chid- 'to cut', strong form chi-na-t-ti 'he cuts', weak form $c h i-n$ - $d$-anti 'they cut', in Aggavamsa's Pali grammar: the class is recognized (rudhādi) ${ }^{57}$ but, since the defining variation does not exist in Pali where forms have been leveled, thus chindati 'he cuts', chindanti 'they cut', the contents are bound to change.

548.56 in Bhāmaha's recension=7.52 in Rāmapānivāda's recension. The influence of the Sanskrit Dhātupātha(s) is clearly perceptible in Bhāmaha's and Rāmapānivāda's commentaries, as they cite the roots mentioned in the sutra with their respective meaning in the locative, e.g. ciñ cayane, śru śravane, ji jaye, lūñ chedane, etc. This amounts to a superimposition of a Sanskrit model since the place of a root in a root-class is determined by its present formation. For instance in Sanskrit collections, ciñ cayane means that the present formation is cayati (Sanskrit class 10), when the Prakrit present taught by Vararuci refers to another class.

55 Same list in Trivikrama 2.4.72. Mārkaṇdeya 7.87 has a shorter list: $h u, s ́ r u, j i, l \bar{u}, d h \bar{u}$ with hunai, sunai, jinai, lunai, dhunai as their present forms. Part of the same material is included in Puruṣottama and is distributed in several sūtras: $7.13(c i), 7.15(l \bar{u}), 7.26(\dot{s} r u)$.

56 This is the habit of Rāmapāṇivāḍa's commentary on Vararuci, e.g., dhunai dhunāai - dhunoti (on 7.52); bhottum-bhoktum (on 7.51), etc.

57 Sadd, roots Nos. 1082-1099 (470-475). 
Roots taken from the Sanskrit model are included with their new conjugation pattern (e.g., rudh 'to obstruct', $y u j$ 'to connect', bhid 'to split' and a few others). But this new pattern, clearly identified through the presence of a consonant group including a nasal (-nda-, -nja-, -nca-) attracts a group of other verbs which would be classified in another category in Sanskrit lists: e.g. lip 'to smear', present limpati, sic 'to sprinkle', present sincati, etc. In Sanskrit these roots belong to class 6 , unaccented thematic presents headed by tudati and including a number of roots strengthened by a penultimate nasal. In his own manner, Aggavamsa shows awareness of the objection which could be raised: why, then, are these verbs not included in the thematic class ( $\mathrm{Pa}$. bhuvādi) which also has verbs having a nasal? He embarks upon a lengthy discussion ${ }^{58}$ arguing that one of the differences lies in the nominal forms: nouns derived from a verb of the thematic class keep their nasal (e.g. saṃkati 'he suspects', sam kā 'suspicion), whereas those derived from a verb of the class rundhädi do not retain the nasal (e.g. chindati 'he cuts', but cheda 'cutting'). Other objections and answers advanced in this debate, interesting as they are, cannot be detailed here. The purpose is simply to show how the Pali grammarian negotiates between an extended model and the facts of the language he deals with.

Comparing the treatment of the verb 'to conquer' in grammars of Prakrit and Pali is interesting. Its inclusion in the Prakrit sūtras (Vararuci 8.56 and Hemacandra 4.241 quoted above) gives emphasis to the present form jinai, but Hemacandra's commentary also mentions jayai as optional. The latter comes from Skt. jayati, which is the common form of the present attested for this verb in the language since the Rgveda. It is likely that Pkt. jinai is a complete innovation, but it is also likely that the existence of the Skt. root $j y \bar{a} / j \bar{l}$ 'to overpower', which has jināti for its present form may have encouraged such a form at some stage. The fact remains that a $-n a$ - present for this root seems to be typical of Middle Indian. Indeed, what we read in Hemacandra's Prakrit grammar in $12^{\text {th }} \mathrm{c}$. Western India for Prakrit, also applies to the two Pali grammars considered here, Kaccāyana and Aggavamsa, but only the latter enters into a critical discussion of the topic. ${ }^{59}$ Aggavamsa first treats ji jaye 'the root $j i$ conveys the idea of victory' as a member of class 1 , the thematic present stems. ${ }^{60}$ He therefore lists examples containing forms such as jayati, or its variant jeti. Nevertheless he ends by saying: 'But this root has also forms such as jināti 'conquers' (present), jinitvā 'having conquered' (absolutive) when it goes

58 Sadd 473,27-475,20.

59 Kaccāyana just quotes the form jinati in the commentary on 451 and a series of forms in the commentary on 560 (see below).

60 Sadd, Dhātumālā $178(344,6)$. 
to the group kiyādi', i.e. the present class where the affix $-n \bar{a}$ - is inserted. ${ }^{61}$ So when he treats this class, he comes again to this root and unfolds a great variety of forms and derivatives based on jināti. ${ }^{62}$ Among them stands the substantive jina, a technical term designating the enlightened person possessed with omniscience in Buddhism, ${ }^{63}$ and also in Jainism (derived from Jina precisely). In both traditions, this noun has been linked with the root ji-, but the end part -na can be explained only from a verb form containing a nasal. There are, then, two possibilities: jina either comes from jyā, jināti 'to overpower' (see above) ${ }^{64}$ or has been encouraged by present forms jināti (late Sanskrit form instead of jayati) 'to conquer'. Conversely, one feels that forms such as Pa.jināti (and Pkt. jinai) may have been favoured because they make the connection with a fundamental noun more obvious (than jayati). The illustrative sentence (identified as coming from the Vinaya) quoted in Kaccāyana remarkably shows the asserted etymological link between the substantive jina and the verb 'to conquer' used in various tenses:

pāpake akusale dhamme jināti, ajini, jinissatī ti jino 'A Jina because he overcomes, has overcome and will overcome evil and bad things'. ${ }^{65}$

As we will just see, the importance attached to synchronical etymological links is not without consequence on grammar.

Keeping to the general Sanskrit frame for presenting and classifying verbal roots does not prevent Aggavamsa from introducing innovations. For instance, he has bhidi vidārane 'the root bhid- in the meaning to cut off' ${ }^{66}$ At first sight this is fully identical with what one reads in Sanskrit lists of roots: bhidira vidārane. ${ }^{67}$ But it is surprising to see that the phrases or quotations adduced as illustrations feature the word bhikkhu 'monk':

he is called bhikkhu because he cuts off the bad or wrong things,

61 Sadd 344, 12-13: imassa pana dhātussa kiyādiganam pattassa jināti jinitvā ty ādīni rūpāni bhavanti.

62 Sadd, Dhātumālā 1238 ji jaye. jināti, vijināti, jinayati, etc. $(495,29-496,12)$. The class kiyādi includes roots No. 1235-1266. - A similar situation is found with thu thutiyam 'the root thu conveys the idea of praise' (Sadd No. 408 p. 363), present form thavati and thu abhitthave same meaning (No. 1241, p. 496) present form thunāti. In the same way 'roots whose verb forms can follow one or the other formation are listed under both classes' in Sanskrit Dhātupāthas (Scharfe 1977, p. 101).

63 Sadd 496,9-10: jina-saddo hi kevalo sabbaññumhi pavattati.

64 See Wackernagel 1926, p. 1 n. 1: 'Auch jina- geht wohl ursprünglich auf jināti 'vergewaltigt' zurück und ist erst nachträglich auf $j i$ - 'siegen' bezogen worden'. See also Mayrhofer 19862001, vol. 3, p. 210.

65 Kaccāyana on $560(184,14)$.

66 Sadd 1089.

67 Sanskrit Dhātupātha 1439. 
a statement explained through a canonical quotation:

one is not a monk insofar as he seeks alms. The one who has expelled bad and good and lives in the world with discrimination, he is the one who is called bhikkhu. ${ }^{68}$

According to linguistic etymology, the word bhikkhu is an agent-noun derived from the root bhiks- (Sanskrit form), bhikkh- (Pali equivalent) 'to seek alms' and refers to the monk as an individual who is dependent on the layfollowers for survival and support. In the Sanskrit lists of roots this root is mentioned as such: bhikṣa bhikșāyām alābhe lābhe ${ } a^{69}$ 'bhikṣ- in the meaning to seek alms whether they are obtained or not'. This root is also taught in our Pali grammar: bhikkha yācane. " bhiks- in the meaning to ask for', and the word bhikkhu is duly mentioned on this occasion but with no further analysis. Under these circumstances, the connection of Pali bhikkhu with the root bhid-and not with the root bhiks-/bhikkh- is clearly unexpected. But it is meaningful: in the non-Brahmanical traditions (Buddhism and Jainism), the so-called heterodoxies, we see that significant terms are reinterpreted on the ethical plane. Synonymic designations for 'monk' are among them. So we have so-called 'popular' or 'folk' etymologies that are not supported linguistically but convey fundamental values in given religious ideologies. ${ }^{71}$ What seems interesting is to see that they are given an additional legitimation through their inclusion in a grammatical work. This is an instance of how the traditional and overwhelming Sanskrit analytical frame is diverted and reappropriated in order to serve a different purpose. This is also in agreement with the initial purpose of the Pali grammar, which is to explain whatever was taught by the Buddha.

The limits of the Sanskrit model applied to the description of the Prakrit verbal lexemes, and the limits of the perception of Prakrits as being "derived" from Sanskrit emerge through the concept of ādes'a 'substitute' which finds a particular application in the field of verb roots or stems. It is used in case the grammarians feel that a given verb which is actually used in Prakrit cannot be traced back to Sanskrit through the application of the phonetic rules which edict regular phonetic changes between Sanskrit and Prakrit. ${ }^{72}$ Thus the concept of "substitute" in this particular understanding is a technique which helps including within a description inspired by the Sanskrit format of the Dhätupātha (root + meaning) the actual variety of

68 Sadd 472,4-7: pāpake akusale dhamme bhindatī ti bhikkhu, tenāha:

"na tena bhikkhu so hoti yāvatā bhikkhate pare

vissam (Sadd ed.: visam) dhammam samādāya bhikkhu hoti na tāvatā,

yo 'dha puñ̃̃añ ca pāpañ ca bāhetvā brahmacariyavā (Sadd ed.: brahmacariyam)

saṃkāya loke carati sa ve bhikkhū ti vuccati" (Dhammapada 266-267).

69 Sanskrit Dhātupātha No. 606.

70 Sadd No. 83: 331,19.

71 For more details see Balbir (in the press).

72 I use the word in its strictest understanding here to illustrate boundary-cases but the Prakrit grammarians recognize several categories of ádeśas, some of which do have some kind of connection with Sanskrit. See Grierson 1924, p. 77. 
Prakrit verbs since these lists include many that are not attested in Sanskrit sources but announce later linguistic evolutions.

In addition, it confines to semantics as the lists delineate the multiple shades of meaning gathering around a fundamental idea "to speak", "to eat", etc. which attract a rich verbal vocabulary. The most important source in this respect is the fourth section of Hemacandra's Prakrit grammar where a number of them are listed (4.1-259). ${ }^{73}$ These substitutes are optional or compulsory, depending on the indicatory letter found at the end of the root as we will see. The pattern is root (genitive case) followed by list of substitutes in the stem form collected together in the form of a nominative dvandva compound. The root is given in its Sanskrit form, with the final indicatory letter.

kather vajjara-pajjara-uppāla-pisuna-saṃha-bolla-cava-jampa-sīsasāhāh,

Of the root kath $+i$ 'to say' (the 10 substitutes are): vajjara-pajjara-uppālapisuna-samgha-bolla-cava-jampa-sīsa-sāha (4.2).

Since the root has the final $i$ as indicator (katheh=genitive of kathi-), it means that beside all these forms, the form kahai, i.e. the Prakrit form obtained from Sanskrit kathayati through Prakrit phonetic rules prescribed earlier in the grammar is also possible. The grammarian is quite aware that the list of substitutes is somewhat heterogenous. Indeed, some of them can easily be traced back to Sanskrit, such as pisunai < Skt. piśunayati 'to calumniate' or jampai < Skt. jalpati which may have a slight derogatory meaning 'to mutter'. But Hemacandra admits that some of them are regional words that are listed by other authors in collections of local words. Nevertheless, he adds, he considers them as root-substitutes so that they may receive the various affixes and produce thousand forms. The process of affixes introduced and removed, he concludes, applies to them as it does to Sanskrit roots. ${ }^{74}$ If we analyse the substitutes, we see that the list results into a broad spectrum of shades of the basic idea "to say" and that some of the Prakrit verbs are effectively continued in modern Indo-Aryan languages. ${ }^{75}$

73 For a complete synoptic table see the pioneering work of Grierson 1924.

74 Commentary on 4.2. Translated in Kahrs 1992a, p. 243-244.

75 This is an instance among several. A similar process is applied for 'to eat'. For the root bhuj, (the eight substitutes are) bhumja-jima-jema-kammânha-samāna-camadha-caḍāh (Hemacandra 4.110). The concept of substitute is necessary because there is no stem $b h u j$ - in Prakrit. Yet, Pkt. bhumjai is not a regional word but a form showing a slight modification of the stem and a passage to the class of thematic presents. As for anhai also 'to eat', it comes from Skt. aśnāti, with regular phonetic change of the consonant group and passage to the class of thematic presents. The other verbs, on the other hand, are regional words, the authenticity of which is guaranteed by corresponding forms in medieval and modern Indo-Aryan languages. In addition, Pkt. jima and jema have correspondences in Sadd, Dhātumālā 658: jimu adane $(411,23)$, present jemati, and camadha seems to have some connection with camu bhaksane (Dhātupāṭha, 1274). 


\section{CONCLUding REMARKS}

The perception of Pali and Prakrit in the respective grammars of these languages may explain why the language used for description is Pali in one case and Sanskrit in the other. The Pali and Prakrit grammars show how technical categories and terms may have been transferred from Sanskrit models. This is no hindrance to the coinage of new terms, albeit marginally (Pali puthuvacana 'plural' in the Saddaniti). The metalanguage used seems to be of limited impact on the descriptions of the verb as evidenced by the Prakrit grammarians. The fact that they use Sanskrit and consider Prakrit as 'derived' from Sanskrit does not prevent them from describing features that are synchronically specific to Prakrit and distinct from Sanskrit. The situation shown by the Pali grammarians is slightly more complex in this respect: although they use Pali, and not Sanskrit, they acknowledge the existence of fundamental classifications used in the Sanskrit grammatical tradition. But their foremost purpose being the elucidation of the Buddha's word, and their explicit source being the scriptures reflecting this teaching, which are profusely quoted, their description of the verb adjusts to the new linguistic reality that Pali represents. Thus, the grammars of the Middle Indian languages, whether they use Pali or Sanskrit as their descriptive languages, are far from being limited to rules of mechanical substitution although they seem to be prevalent at first sight.

\section{AbBreviations}

Kacc: see below Kaccāyana

MIA $=\quad$ Middle Indo-Aryan

Pa. $=\quad$ Pali

Pkt. $=\quad$ Prakrit

Sadd: see below Saddanīti

Skt. $=\quad$ Sanskrit

\section{BIBLIOGRAPHIE}

\section{Primary sources}

Aggavaṃsa: see under Saddaniti

Dhātupātha: The Dhātupātha of Pānini with the Dhātvartha Prakāśikā, Notes by Pt. Kanakalāl Śarmā, Varanasi, The Chowkhamba Sanskrit Series Office, 1969 (The Haridas Sanskrit Series 281).

Hemacandra:

Hemacandra's Grammatik der Prâkritsprachen (Siddhahemacandram Adhyâya VIII) mit kritischen und erläuternden Anmerkungen herausgegeben von Richard Pischel, 187780 (reprint Osnabrück, 1969).

Prakrit Grammar of Hemacandra being the Eighth Adhyāya of his Siddha-HemaSabdānuśāsana. Revised edition with notes and index of Prakrit words by P.L. Vaidya, Bombay, 1958. 
Kaccāyana:

D’Alwis, James, 1863. An Introduction to Kachchàyana's Pàli Grammar of the Pàli Language with an introduction, appendices, notes \&c, Colombo.

Pind, Ole Holten, 2013. Kaccāyana and Kaccāyanavutti. Bristol: The Pali Text Society.

Senart, Emile, 1871. "Kaccâyana et la littérature grammaticale du Pâli”, Paris, Journal Asiatique.

Vidyabhusana, Satis Chandra, 1901. Kaccayana's Pali Grammar, edited in Devanagari Character and Translated into English, Calcutta, Mahabodhi Society.

Mārkandeya's Prākrta-sarvasva, critically edited with introduction, variant readings and useful indices etc. by Dr. Krishna Chandra Acharya, Ahmedabad, Prakrit Text Society, 1968 (Prakrit Text Society Series 11).

Puruṣottama: Le Prākrtānuśásana de Puruṣottama par Luigia Nitti-Dolci, Paris, Cahiers de la Société Asiatique, 1938.

Rāmaśarman:

Édition de la première śākhā du Prākrtakalpataru de Rāmaśarman par Luigia Nitti-Dolci, Paris, Librairie ancienne Honoré Champion, 1939.

Rāmaśarman's Prākrtakalpataru with introduction, English translation, notes and appendices by Manomohan Ghosh, The Asiatic Society, Calcutta, 1954.

Saddanīti: Helmer Smith, La grammaire palie d'Aggavamsa, Lund, C.W.K. Gleerup, 192866.â [References are to pages and lines of this edition or, when applying, to the rootnumber].

Trivikrama: Prakrit Grammar of Trivikrama with his own commentary or PrākrtaŚabdānuśāsanam savrttikam. Critically edited with various readings, an introduction and appendices, etc. by Dr. P.L. Vaidya, Jaina Saṃskṛti Saṃrakṣaka Saṃgha, Sholapur, 1954.

Vararuci:

The Prākrita-Prakāśa or The Prākrit Grammar of Vararuchi with the commentary (Manoramā) of Bhāmaha. The first complete edition .. by E.B. Cowell, Hertford, 1854 (reprint Punthi Pustak, Calcutta, 1962).

Prākrta-Prakāśa of Vararuci with the commentary of Rāmapāninivāda, Madras, The Adyar Library, 1946.

\section{Secondary sources}

Andersen, Dines, \& Smith, Helmer, 1921. The Pāli Dhātupātha and the Dhātumañjūsā edited with indexes. København.

Balbir, Nalini (in the press), "Les débuts de la scolastique jaina: stratégies interprétatives et réception", Les scolastiques indiennes: naissances, développements, interactions, ed. by E. Aussant and G. Colas, Paris, EFEO.

Bloch, Jules, 1965. Indo-Aryan from the Vedas to Modern Times, English edition largely revised by the author and translated by Alfred Master, Librairie d'Amérique et d'Orient, Paris, Adrien Maisonneuve.

Cardona, George and Jain, Dhanesh, 2003. The Indo-Aryan Languages, London, Routledge.

Deokar, Mahesh A., 2008. Technical Terms and Technique of the Pali and the Sanskrit Grammars, Sarnath, Varanasi, Central Institute of Higher Tibetan Studies (Miscellaneous Series XXIII).

Deokar, Mahesh A., 2012a. Understanding Māgadhī: The Pure Speech of the Buddha, Journal of the Centre for Buddhist Studies, Sri Lanka vol. 10, 1-17.

- 2012b, "Some Probable Sanskrit Sources of the Pali Grammarians with Special Reference to Aggavamsa", Samskritasādhutā, Studies in Honour of Professor Ashok Aklujkar, ed. Chikafumi Watanabe, Michele Desmarais, and Yoshichika Honda, New Delhi, Printworld Publishers, 150-171.

Drocco, Andrea, 2012. "Eternal Sanskrit and the meaning of the tripartite Prakrit terminology tatsama, tadbhava and deśr’’, Linguistica e Filologia 32, 119-136.

Franke, Rudolf Otto, 1902. Geschichte und Kritik der einheimischen Pāli-Grammatik und Lexicographie, Strassburg. 
Grierson, George Abraham, 1924. "The Prakrit Dhātv-ādeśas according to the Western and the Eastern Schools of Prakrit Grammarians", Memoirs of the Asiatic Society of Bengal vol. $8,2,77-170$.

von Hinüber, Oskar, 1983. "Notes on the Pāli Tradition in Burma", Beiträge zur Überlieferungsgeschichte des Buddhismus in Birma, I, NAWG I. Philologischhistorische Klasse, Jg. 1983, Nr. 3, 65-79.

Houben, Jan E.M., 1994. "Bhartrhari's Familiarity with Jainism", Annals of the Bhandarkar Oriental Research Institute 75, 1-4, 1-24.-Postscript: Earlier Indian Authors and Linguistic Change, ibidem, 255-256.

Katre, S.M., 1940. The Roots of the Pāli Dhātupāthas, reprinted from The Bulletin of the Deccan College Research Institute, vol. I Nos. 2-4.

Kahrs, Eivind, 1992a. "What is a Tadbhava Word?", Indo-Iranian Journal 35, 225-249.

-1992b. "Exploring the Saddanīti", Journal of the Pāli Text Society 17, 1-212.

Lassen, Christian, 1837. Institutiones Linguae Pracriticae, Bonn.

Mayrhofer, Manfred, 1986-2001. Etymologisches Wörterbuch des altindoarischen, Heidelberg, C. Winter.

Nitti-Dolci, Luigia, 1938. Les grammairiens prakrits, Paris.-English translation: The Prākrita Grammarians translated from the French by Prabhākara Jhā, Delhi, Motilal Banarsidass, 1972.

Palsule, Gajanan Balkrishna, 1955. A Concordance of Sanskrit Dhātupāthas (with index of meanings), Poona, Deccan College (Deccan College Dissertation Series 14).

Pind, Ole Holten, 1995. "Pāli and the Pāli Grammarians: The Methodology of the Pāli Grammarians", in Sauhrdyamangalam: Studies in Honour of Siegfried Lienhard on His 70th Birthday, Stockholm, The Association of Oriental Studies, 281-97.

- 2012. "Pāli Grammar and Grammarians from Buddhaghosa to Vajirabuddhi: A Survey", Journal of the Pāli Text Society 31, 57-124.

Pischel, Richard, 1900. Grammatik der Prākrtt-Sprachen, Strassburg.

Renou, Louis, 1957. "Kaccāyana et le Kātantra", Études védiques et pāninéennes 3, Paris, De Boccard, 127-133.

Ruiz Falqués, Aleix, 2017. “The Role of Pāli Grammar in Burmese Buddhism”, Journal of Burma Studies, 21, 1, June 2017, 1-96.

Scharfe, Hartmurt, 1977. Grammatical Literature. A History of Indian Literature, vol. 5, fasc. 2, ed. Jan Gonda, Wiesbaden.

Verbeke, Saartje, 2010. Three Prakrit Grammars, Hindi Granth Karyalay, Mumbai.

Wackernagel, Jacob, 1926. "Kleine Beiträge zur indischen Wortkunde", Beiträge zur Literaturwissenschaft und Geistesgeschichte Indiens, Festgabe Hermann Jacobi zum 75. Geburtstag dargebracht von Freunden, Kollegen und Schülern, herausgegeben von Willibald Kirfel, Kommissionsverlag Fritz Klopp, Bonn, 1-17. 